\title{
Arbuscular mycorrhizal fungi in a voltzialean conifer from the Triassic of Antarctica
}

\author{
Carla J. Harper ${ }^{\text {a,b, } *}$, Thomas N. Taylor ${ }^{\text {a,b }}$, Michael Krings ${ }^{\text {a,b,c,d }}$, Edith L. Taylor ${ }^{\text {a,b }}$ \\ a Department of Ecology and Evolutionary Biology, University of Kansas, Lawrence, KS 66045-7534, USA \\ b Natural History Museum and Biodiversity Institute, University of Kansas, Lawrence, KS 66045-7534, USA \\ c Department für Geo- und Umweltwissenschaften, Paläontologie und Geobiologie, Ludwig-Maximilians-Universität, Richard-Wagner-Straße 10, 80333 Munich, Germany \\ d Bayerische Staatssammlung für Paläontologie und Geologie, Richard-Wagner-Straße 10, 80333 Munich, Germany
}

\section{A R T I C L E I N F O}

\section{Article history:}

Received 17 September 2014

Received in revised form 6 January 2015

Accepted 7 January 2015

Available online 24 January 2015

\section{Keywords:}

Fossil fungus

Arum-type arbuscule

Paleoecology

Plant-fungal interaction

Notophytum krauselii

\begin{abstract}
A B S T R A C T
Mycorrhizas are intimate mutualistic relationships between plants and fungi that represent an integra component of ancient and extant ecosystems. These symbioses have been established for at least 400 million years and are found in numerous fossil plant groups, including early land plants, seed ferns, and cordaitaleans. In modern ecosystems, it is common for different types of mycorrhizas to occur within a single plant; however, fossil evidence of this is exceedingly scarce. A vesicular-arbuscular mycorrhiza is described in Notophytum krauselii (voltzialean conifers) based on permineralizations from the Middle Triassic of Antarctica. This symbiosis occurs in young non-nodular roots and is characterized by fungal hyphae, vesicles, and arbuscules within a discrete zone of the root cortex. Together with the mycorrhizal root nodules described previously for $N$. krauselii, this discovery represents only the second record of multiple types of mycorrhizae occurring within the same fossil plant, and provides important information on the system of interactions that may have allowed voltzialean conifers to survive in an extreme paleoenvironment.
\end{abstract}

(c) 2015 Elsevier B.V. All rights reserved.

\section{Introduction}

Belowground ecosystems incorporate highly integrated components that form complex and dynamic communities. For example, in forest ecosystems there are just as many abiotic and biotic interactions within the rhizosphere as there are above ground (Fitter et al., 2005; Wang and Qiu, 2006). Among these diverse rhizosphere interactions are mycorrhizal symbioses, the mutualistic relationship between a fungus and plant in which both partners benefit from the exchange of nutrients (Simard and Durall, 2004). This ancient intimate relationship has been suggested as a necessary preadaptation that made it possible for plants to colonize the terrestrial realm (Pirozynski and Malloch, 1975; Simon et al., 1993; Fitter et al., 2005; Bonfante and Selosse, 2010). Today, mycorrhizal associations are common among a large majority (i.e., an estimated $>80 \%$ ) of extant plant families, and include most bryophytes, lycophytes, pteridophytes, gymnosperms, and angiosperms (Simard and Durall, 2004; Wang and Qiu, 2006). Plant-fungal relationships closely resembling extant mycorrhizas with regard to structure and morphology have also been reported in several extinct lineages and species of plants, e.g., early land plants (rhyniophytes), arborescent lycopsids, seed ferns, cordaitaleans, (e.g., Remy et al., 1994; Krings et al., 2007;

\footnotetext{
* Corresponding author at: Department of Ecology and Evolutionary Biology, University of Kansas, Lawrence, KS 66045-7534, USA. Tel.: +1 7858644255.

E-mail address: charper@ku.edu (C.J. Harper).
}

Strullu-Derrien et al., 2009; Krings et al., 2011; Harper et al., 2013), and fossil representatives of living plant groups, including conifers and flowering plants (e.g., LePage et al., 1997; Stockey et al., 2001; Beimforde et al., 2011).

Triassic permineralized peats from the central Transantarctic Mountains of Antarctica have preserved an exceptionally diverse assemblage of fossil fungi, including a putative trichomycete (White and Taylor, 1989a), a basidiomycete (Osborn and Taylor, 1989), several examples of zygomycetous fungi (White and Taylor, 1989b; Krings et al., 2012), fungal “sporocarps" (White and Taylor, 1989c), and possible saprotrophic fungi in reproductive structures (Bergene et al., 2013). Moreover, glomeromycotan fungi involved in endomycorrhizal associations were reported in the cycad Antarcticycas schopfii (Stubblefield et al., 1987a,b; Phipps and Taylor, 1996), and mycorrhizal root nodules in narrow rootlets of the voltzialean conifer Notophytum krauselii (Schwendemann et al., 2011). The latter taxon is among the most completely known anatomically preserved plants of the Triassic paleoecosystems in Antarctica (Bomfleur et al., 2013). It can be viewed as a model system for studies of paleoecology in Triassic Gondwanan ecosystems due to its abundance, distribution throughout Gondwana, and known descriptions of the morphology and anatomy of roots, stems, branches, trunks (i.e., N. krauselii; Meyer-Berthaud and Taylor, 1991, 1992), leaves (i.e., compressions: Heidiphyllum elongatum, permineralizations: Notophytum leaves; Anderson, 1978; Axsmith et al., 1998), reproductive structures, i.e., seed cones (Telemachus sp. 
and Parasciadopitys aequata; Yao et al., 1993; Escapa et al., 2010), pollen cones (Switzianthus sp.; Anderson and Anderson, 2003; Bomfleur et al., 2011), and bisaccate pollen of the Alisporites type (e.g., Yao et al., 1993), as well as microbial associations (e.g., Bomfleur et al., 2013).

In this study we report a vesicular-arbuscular endomycorrhiza (VAM or AM) that occurs in non-nodular roots of $N$. krauselii. The fungal partner spreads through the intercellular system of the outer and middle root cortex and consists of aseptate hyphae, thin-walled vesicles, and intracellular arbuscules within a discrete zone of the host cortex. The discovery of an AM in addition to the mycorrhizal root nodules in $N$. krauselii is important because it provides evidence that different types of endomycorrhizal associations occurred within Antarctic voltzialean conifers. The mycorrhizal systems (simultaneously or alternately) may have contributed to the system of adaptations that enabled these plants to survive in a high-latitude peat-forming environment as has been suggested of this part of the Antarctic continent during the Triassic.

\section{Geological setting, material, and methods}

\subsection{Geological setting}

The fossils occur in permineralized (silicified) peat from the Fremouw Formation in the central Transantarctic Mountains of Antarctica (Taylor et al., 1986; Cúneo et al., 2003; Faure and Mensing, 2010). The Fremouw Formation is a $620-750 \mathrm{~m}$ thick siliclastic succession deposited by low sinuosity, braided streams (Faure and Mensing, 2010). The fossils occur within several allochthonous clasts that are at approximately the same stratigraphic level within a trough-crossbedded, mediumgrained, greenish-gray volcaniclastic sandstone. Permineralized peat is found at a single level at the Fremouw Peak locality, approximately $30 \mathrm{~m}$ below the top of the formation. Blocks of peat were likely rafted into their current position during a flooding event that caused them to be stranded on sand bars prior to permineralization (Taylor et al., 1989) and isolated into individual lenses within the outcrop. The peat was silicified after burial in its current position and the age of the fossil plants within the peat is equivalent to the surrounding clastic sediments, i.e., fluvial sandstone, which also contains trunks of wood of equivalent age to the peat (Decombeix et al., 2014). The silica source for the permineralization is interpreted to be the result of the dissolution of siliceous, volcanic detritus that was abundant in the upper Fremouw Formation. The peat and surrounding material have been dated as early Middle Triassic (Anisian) based on palynomorphs and nearby vertebrate fossils (Farabee et al., 1990; Hammer, 1990; Sidor et al., 2008; Faure and Mensing, 2010).

\subsection{Material}

The peat blocks used in this study contain abundant components attributable to the voltzialean conifers, including axes of $N$. krauselii (Plate I, 1) characterized by eustelic woody stems, roots of $N$. krauselii characterized by a distinctive phi layer suggesting that the plants may have grown in a fluctuating water table environment (Millay et al., 1987; Taylor and Ryberg, 2007), permineralized N. krauselii leaves (Plate I, 2), numerous Alisporites pollen grains (Plate I, 3), and ovules of Parasciadopitys (Plate I, 4).

Fossil roots in general are difficult to identify at any systematic level because the characters used to define them are relatively uniform. However, $N$. krauselii roots and aerial axes/stems do share several anatomical features that make it possible to assign the roots with confidence to the stems, which in turn are correlated with other vegetative and reproductive organs (e.g., Meyer-Berthaud and Taylor, 1991; Escapa et al., 2011).

The thin sections prepared for this study are composed almost entirely of roots in various planes of section, which provide the opportunity to examine slightly different stages of development and to compare the anatomical features with those roots described previously and assigned to N. krauselii (Meyer-Berthaud and Taylor, 1991, 1992; Bomfleur et al., 2013). This also makes it possible to trace the distribution of the fungus within the roots and to analyze where it occurs within the tissue systems. Mature roots contain a distinct zone of primary xylem, well-defined endodermis, secondary xylem, cortical tissues, and a poorly preserved and locally difficult to discern epidermis (Plate I, 5). Mature roots, however, are rarely encountered in the peat blocks relative to the smaller, immature rootlets lacking secondary xylem. The smaller rootlets occur singly or in distinct clusters (Plate I, 6), vary from 0.5 to $5 \mathrm{~mm}$ in diameter with most between 1 and $2.2 \mathrm{~mm}$; some are sectioned in a way to show well-defined apices. Generally, the stele of these rootlets is poorly preserved, but the endodermis is present; the cortex of smaller rootlets is approximately 4-6 cell layers thick, and appears similar to that in mature roots; the epidermis is difficult to discern.

\subsection{Methods}

Fossil specimens were initially prepared according to standard acetate peel techniques utilizing hydrofluoric acid (Joy et al., 1956; Galtier and Phillips, 1999) to survey the material for fungi, including roots that may show evidence of mycorrhizal colonization. For promising specimens standard thin sections were prepared (Hass and Rowe, 1999), but with the following modifications. Pieces of peat were mounted on microscope slides using Hillquist 2-part A-B epoxy compound and cut with a Buehler Petrothin ${ }^{\circledR}$ thin-sectioning machine to a thickness of $\sim 250 \mu \mathrm{m}$. The wafer was then ground to a thickness of 50-65 $\mu \mathrm{m}$ and analyzed using a Leica DM5000B transmitted-light compound microscope. Digital images were taken with a Leica DC500 digital camera attachment and minimally processed using Adobe Photoshop CS6 Version 13.0 x64 (@1990-2012, Adobe Systems). When suitable specimens were identified, multiple micrographs of the same specimen were recorded at different focal planes and compiled to produce composite images (e.g., Bercovici et al., 2009). The images were stacked in Adobe Photoshop CS6 and specific areas were modified to reveal the complete three-dimensional image as seen in the thin sections. Several images were also digitally focal stacked using Helicon Focus software (Method B, Radius 8, Smoothing 4) in order to study intricate areas of the specimens (e.g., Saupe and Selden, 2009). Measurements were taken using Image $1.48 \mathrm{~b}$ software (Abràmoff et al., 2004). Specimens and slides are deposited in the Paleobotanical Collections, Natural History Museum and Biodiversity Institute, University of Kansas (KUPB) under specimen accession numbers 26590 , 30000-30007.

\section{Results: fungi in N. krauselii}

More than 50 young $N$. krauselii rootlets have been discovered that are characterized by a distinct, continuous zone of apparently more opaque cells positioned in the cortex approximately 3-4 cell layers below the epidermis. This zone is $2-5$ cells thick and can readily be recognized in both transverse (Plate $I, 7$ ) and longitudinal sections (Plate I, 8) because of the concentration of fungi.

This zone within the root cortex appears more opaque because it is densely packed with multi-branched intracellular arbuscules attached to intercellular trunk hyphae, and sparsely dispersed vesicles positioned terminally on parental (branch) hyphae (Plate II, 8). Prominent hyphae $(\sim 7 \mu \mathrm{m}$ in diameter) are perpendicular, septate, and ramify throughout the zone (Plate II, 1). It is interesting to note that evidence of this fungus has not been found in any cells of the stele, the cortical tissues outside of the distinct zone, epidermis, or in the surrounding matrix. However, a few rootlets host other hyphae that are generally larger $(\sim 15 \mu \mathrm{m}$ diameter) (Plate II, 2). These hyphae have not been found attached to vesicles or arbuscules, and likely represent another fungus present in the rootlet or represent trunk hyphae from which smaller lateral hyphae branch to 


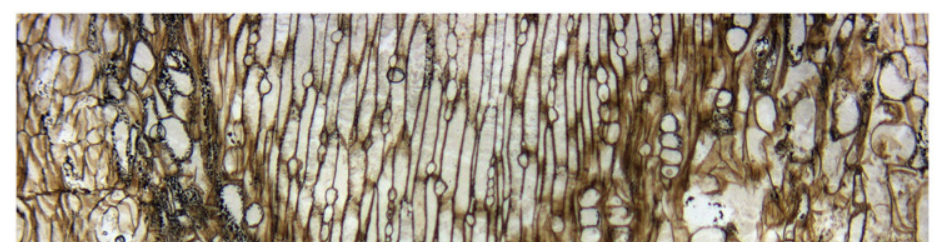

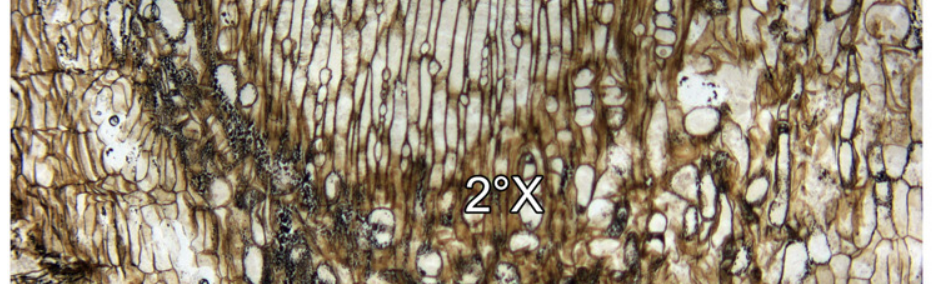
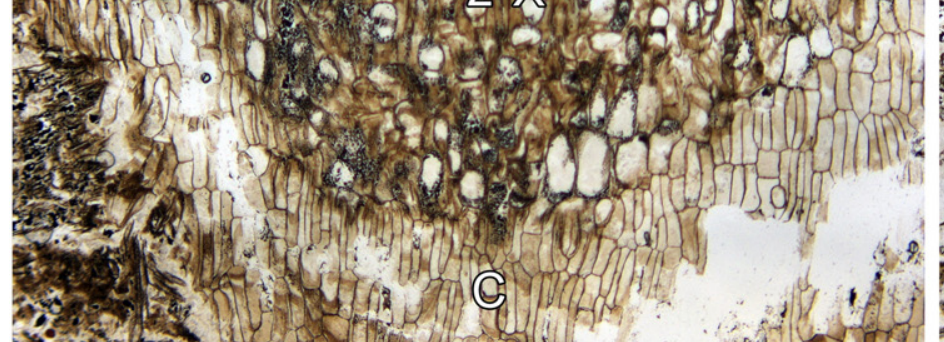

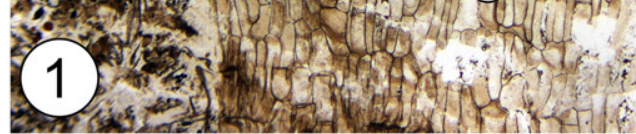

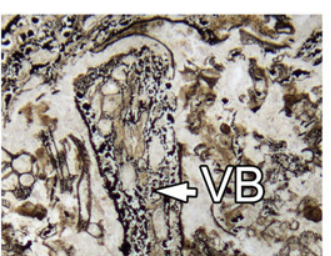
- in 10 $3=-8$

$x^{2}$
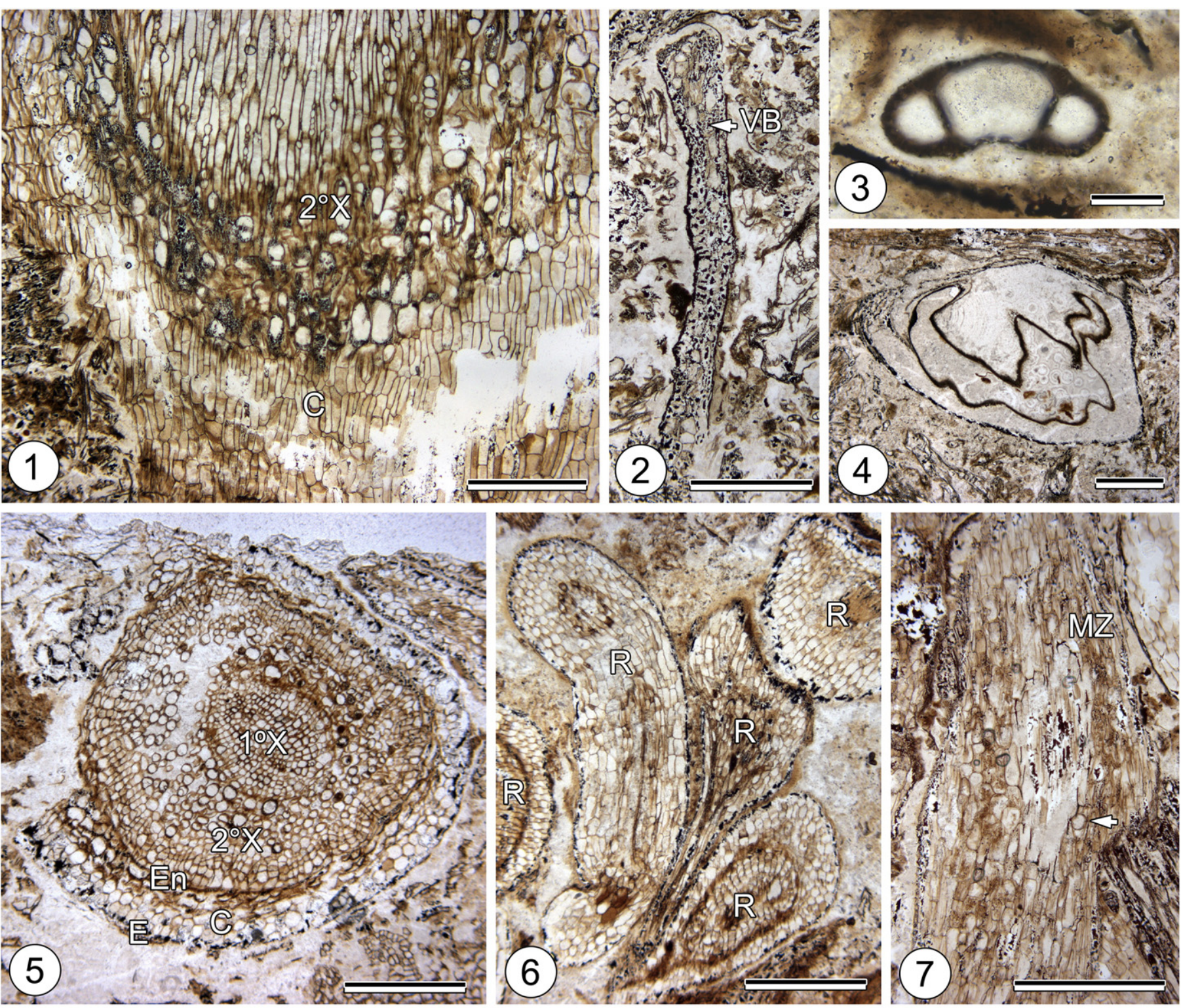

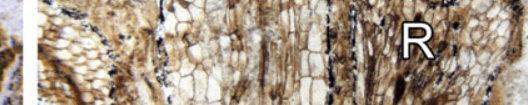

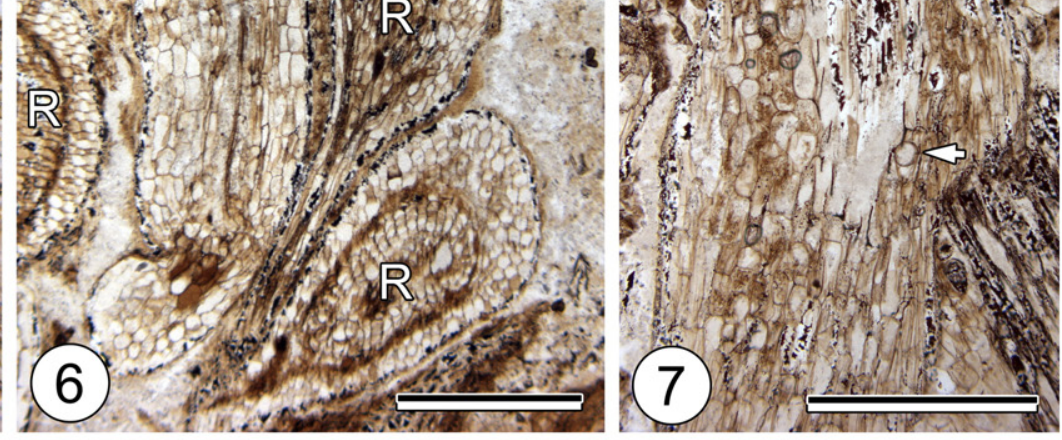

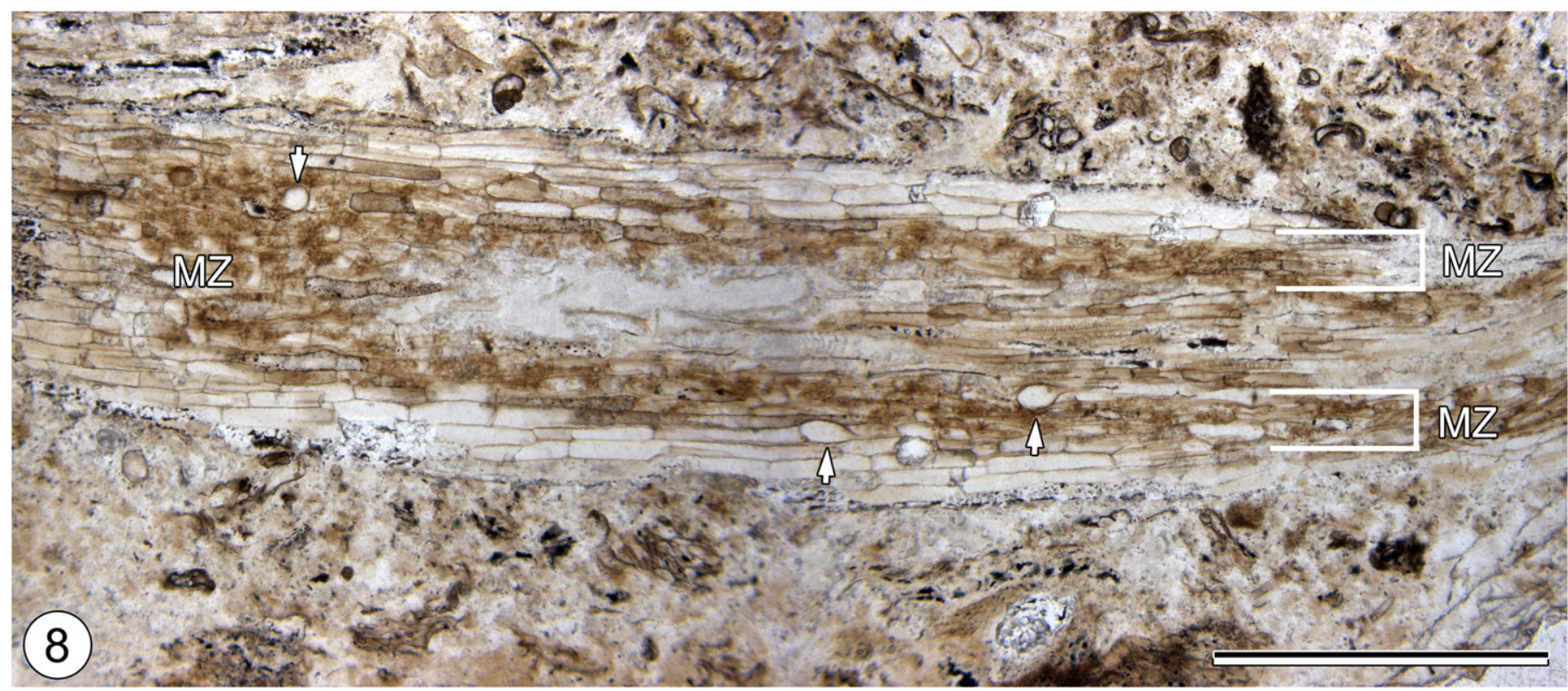


produce arbuscules. At this time we can only speculate on the ecological affinity of the larger hyphal type. It is possible that this may represent a saprotrophic or parasitic fungus; however, we have no direct evidence to support this, i.e., degradation of the cell walls or host responses. There are amorphous structures within cells (see Plate II, 14) that we have interpreted as preservational artifacts or biomimetic structures, but may also represent remnants of fungal decomposition. The smaller hyphae are more common and produce right angle branches (Plate II, 3 ), possible T- or cruciform branching (Plate II, 4), Y-branching (Plate II, 5), and anastomoses to $\mathrm{H}$-junctions (Plate II, 7); hyphae lack a septum at each division, but can produce septa after division or branching. In rare examples, the hyphae produce a swelling or an enlarged region with some of these structures separated by a septum (Plate II, 6).

The individual branched units that make up the arbuscule are difficult to distinguish because of their small size and three-dimensional organization; the structure of the arbuscule ranges from bulbous to narrowly tapering points of the branching hyphae. Although the composition and structure of the individual arbuscules is consistent, the point of attachment of the arbuscules is variable, with the majority occurring at the ends of hyphae (Plate II, 9). Other attachment points result from a right angle branch of vegetative hyphae (Plate II, 10) or, less commonly, arbuscules develop directly from an individual hypha (Plate II, 11).

Vesicles are attached to the same type of vegetative hypha that produces the arbuscules. Two distinct types of vesicles are present in the rootlets: (1) globose or spheroidal (Plate II, 12) and (2) oblong to elliptical (Plate II, 13-14). Vesicle development is initiated soon after arbuscules are formed and have been hypothesized to function as storage units that typically contain lipids and cytoplasm in mycorrhizal associations (Cooper and Lösel, 1978). In rare instances, however, vesicles develop thick walls and may function as propagules in older, mature roots (Biermann and Linderman, 1983). Globose, spheroidal vesicles are $25-30 \mu \mathrm{m}$ in diameter with an average diameter of $28 \mu \mathrm{m}$. The oblong to elliptical vesicles are $65-78 \mu \mathrm{m}$ in length with an average of $75 \mu \mathrm{m}$. At the narrowest portion of the vesicle, the width can range from 10 to $15 \mu \mathrm{m}$ in diameter with an average width of $13 \mu \mathrm{m}$. The widest portion of the vesicle is $35-40 \mu \mathrm{m}$ in diameter with an average diameter of $36 \mu \mathrm{m}$. Both globose and oblong vesicles are smooth-walled, opaque, and with a uniform wall approximately $0.5 \mu \mathrm{m}$ thick. A single perpendicular septum occurs at the base of each vesicle. A right-angle branch from a vegetative hypha produces the globose or spheroidal vesicles. In contrast, oblong or elliptical vesicles are produced at the terminal end of an individual hypha. Vesicles lack contents and occur inside the lumen of individual cortical cells. Only mature, fully developed vesicles have been observed in the rootlets; immature or developing vesicles have not been identified. It is possible that the bulging or swollen areas in individual hyphae (e.g., Plate II, 6) represent a developmental stage in vesicle production.

\section{Discussion}

Voltzialean conifers are a group of transitional gymnosperms that is generally considered to be sister to the Cordaitales, primarily based on a shared suite of characters in the reproductive structures (Florin, 1951; Hernandez-Castillo et al., 2001; Rothwell et al., 2005; Taylor et al., 2009). The first report of a mycorrhiza in voltzialean conifers was in the form of spheroidal mycorrhizal root nodules in $N$. krauselii from the Triassic of Antarctica (Schwendemann et al., 2011). These root nodules are specialized outgrowths that develop on young roots and function as the site of endomycorrhizal fungal development. In extant conifers producing mycorrhizal nodules, these structures typically form in rootlets that are close to the soil surface (Russell et al., 2002).

The fungi reported in this study occur in small secondary, young rootlets of $N$. krauselii that differ from nodule-producing roots; the anatomical features of the fungus are also different from those in the nodules. The mycorrhizal fungus reported here is characterized by distinctive vesicles and arbuscules that occur exclusively within a well-defined zone of the ontogenetically immature host rootlet cortical tissue. In contrast to the fungi described by Schwendemann et al. (2011), the fungus in this study differs by producing globose and oblong vesicles; fungi within the $N$. krauselii root nodules do not contain multiple types of vesicles (only spherical types were described). The fungus in this study also differs by having multiple types of arbuscule-tohyphal attachment types and does not have associated extrarhizal spores. This complement of features corresponds with morphologies seen in many extant and several other fossil arbuscular mycorrhizal (AM-)fungi (e.g., Bonfante-Fasolo, 1984; Peterson and Farquhar, 1994; Brundrett, 2004; Dickson, 2004). The oldest fossil record of AM fungi comes from the Lower Devonian ( $408 \mathrm{Ma}$ ) Rhynie chert, where the fungus occurs in a well-defined zone of the cortex of the prostrate and upright axes of the early land plant Aglaophyton major (Remy et al., 1994). A similar mycorrhizal association has recently also been suggested for the Rhynie chert land plant Horneophyton lignieri (Strullu-Derrien et al., 2014). Fossil AM fungi that produce arbuscules exclusively within a specialized zone of the host cortex have also been reported to occur in Radiculites-type cordaitalean rootlets from the Carboniferous of France (Strullu-Derrien et al., 2009), stigmarian appendages from the Carboniferous of Great Britain (Krings et al., 2011), and the Triassic cycad A. schopfii (Stubblefield et al., 1987a,b; Phipps and Taylor, 1996). Based on the structural correspondences of the fossils described in this study to extant and other fossil AM associations, we interpret the fossil fungi in $N$. krauselii as representing the fungal partner in a vesicular-arbuscular mycorrhiza.

Arbuscule morphology in extant plants includes two principle morphological types, i.e., the Paris-type, characterized by coiled hyphae, arbuscules, and predominantly intracellular development, and the Arum-type, characterized by highly dichotomized arbuscules and predominantly intercellular development (Dickson, 2004). The combination of characters herein, such as the highly dichotomizing hyphae and various attachment points to vegetative hyphae, suggest that the arbuscules in $N$. krauselii are most like those of the Arum-type. The presence of an Arum-type endomycorrhizal morphology in N. krauselii is interesting because the vast majority of arbuscular mycorrhizas in modern gymnosperms, with the possible exception of Gingko biloba, is of the Paris-type (Breuninger et al., 2000).

Glomeromycotan systematics and taxonomy today are based primarily on molecular-phylogenetic evidence, and morphological characters when congruent with gene phylogenies. The exclusive use of morphological data for Glomeromycota taxonomy can be used in exceptional cases, such as fossil taxa, when supporting molecular data are ambiguous or unavailable. Based on the consensus classification incorporating molecular-phylogenetic and morphological data, there are ten families of the Glomeromycota that have been identified: Acaulosporaceae, Ambisporaceae, Archaeosporaceae, Paraglomeraceae, Claroideoglomeraceae, Diversisporaceae, Geosiphonaceae, Gigasporaceae, Pacisporaceae, and Glomeraceae (Schüßler and Walker, 2010; Redecker et al., 2013). Each of these families has distinct morphological area of mycorrhizal zone. Arrows $=$ vesicles. Slide no. 26590; scale bar $=500 \mu \mathrm{m}$. 

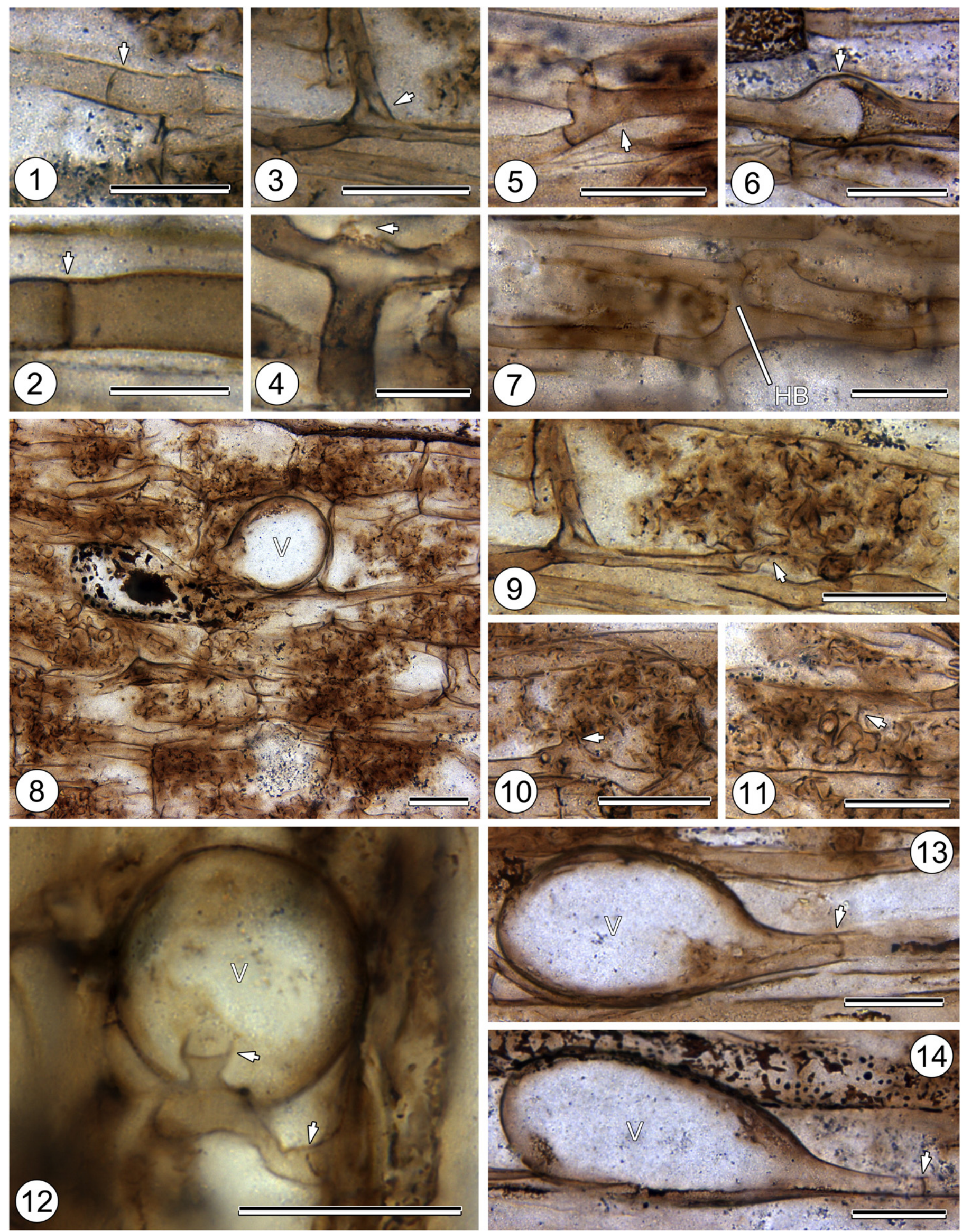
characters and in some cases, unique ecological niches that can be used to determine the closest systematic affinity of fossil endomycorrhizal fungi. The endomycorrhiza that occurs in the young rootlets of $N$. krauselii is characterized by hyphae that are straight or occasionally sinuous, and seldom produce septa. The vegetative hyphae branch dichotomously and produce Y-branches and $\mathrm{H}$-junctions, with some larger hyphae that contain occasional swellings. The arbuscules are produced on small trunks of various attachment types, i.e., right angle or no trunk from a parental hypha, or develop terminally on the parental hypha, with bulbous secondary branching; vesicles are ellipsoidal to globose, lateral and terminal, and a septum is present at the base. Additionally, no asexual or extraradical spores, saccules, or auxiliary spores have been found associated with this fungus.

Many of the families of the Glomeromycota do not contain these characters and can be eliminated in considerations as to the affinity of the $N$. krauselii mycorrhizal fungus: (1) the Acaulosporaceae produce endomycorrhizae with ellipsoidal to irregular or knobby vesicles (Morton and Benny, 1990); (2) members of the Ambisporaceae are characterized by the production and developmental processes of asexual spores (e.g., glomoid and/or acaulosporid) and spore wall structure and saccules; $(3,4)$ all members of the Archaeosporaceae and Paraglomaceae produce mycorrhizae that lack vesicles (Morton and Redecker, 2001); (5) the Claroideoglomeraceae is also known as the phylogenetic Glomus Group B, and is typified by glomoid spores that form in substrate or rarely in decaying roots, and the development of an inner wall that is produced separately or an apparent 'endospore' (Schüßler and Walker, 2010); (6) the Diversisporaceae produces arbuscular mycorrhizas with or without vesicles, with or without auxiliary cells, and are characterized by the formation of glomoid spores (Walker and Schüßler, 2004); (7) the Geosiphonaceae are characterized by specific asexual spore wall characters and are unique because one species produces an endocytosymbioses with cyanobacteria (Schüßler, 2002); (8) the Gigasporaceae is primarily characterized by spore cell wall morphology, germination shield patterns and development, and auxiliary cell morphology. Additionally, Gigapora spp. form endomycorrhizas with arbuscules, coiling hyphae, and do not produce vesicles (Walker and Sanders, 1986); (9) the Pacisporaceae are primarily characterized by spore surface structure, spore wall ornamentation, spore color and size, and germination shield development (Oehl and Sieverding, 2004).

(10) The Glomeraceae contains the largest number of species, i.e., Glomus spp., of the Glomeromycota. Morphological characters of the endomycorrhizas formed by Glomeraceae include finely branched arbuscules with narrow trunks ( $<4 \mu \mathrm{m}$ in diameter), intercellular, typically straight hyphae (1.5-5 $\mu \mathrm{m}$ in diameter) that can also produce diagnostic H-branching, intracellular hyphae (2-4 $\mu \mathrm{m}$ wide) that rarely coil, and vesicles that are generally elliptical to spheroidal (Pirozynski and Dalpé, 1989). The fossil fungus described in this study shares the most characters (i.e., finely branched arbuscules, $\mathrm{H}$-branching, and elliptical and spheroidal vesicles) with the Glomeraceae, specifically with the genus, Glomus.

The presence of AM in N. krauselii indicates that mycorrhizal associations in this Triassic conifer did not exclusively occur in the form of root nodules, but that some also entered into a different type of mycorrhizal association (i.e., AM) within non-nodule-forming rootlets. It remains unresolved, however, as to whether these two different mycorrhizal associations occurred simultaneously in this plant, perhaps located in different parts of the root system (see below), or the plant was able to shift between different mycorrhizal associations. For example, it is possible that germlings and juvenile plants relied on AM, whereas the larger plants with more extensive root systems developed root nodules. Because nodules and AM have not been discovered together in the same roots or in different roots in organic connection, it is also possible that perhaps the two types of mycorrhizal association did not occur in the same individuals, but rather that there were some trees with root nodules and others that had AM.

Modern AM fungi differ from root nodule fungi not only with regard to structure and morphology, but also with regard to the part of the root system that they colonize, and the relative position they occupy in the soil column. For example, in podocarps (Podocarpaceae) the mycorrhizal root nodules occur in subsurface roots (Dickie and Holdaway, 2011), whereas AM fungi are typically found in young, developing roots, which can spread both laterally and vertically throughout the entire soil column (Vogt et al., 1981). The latter mycorrhizal association in the young rootlets is likely important in the initial establishment of the plants in nutrient-poor soils (Rillig and Mummey, 2006). It has also been suggested that root nodules increase the extent of mycorrhizal colonization, while minimizing the cost that would be associated with developing an extensive root system (McGee et al., 1999; Dickie and Holdaway, 2011). Nevertheless, the exact functions of mycorrhizal root nodules remain elusive. One important difference between the host cells containing AM fungi in the form of arbuscules and those cells containing them in nodules is that the cells of the latter atrophy after the arbuscules have ceased to function and the nodules are eventually abscised, whereas cortical cells invaded by typical AM fungi remain alive after arbuscules have collapsed, and these cells can subsequently host new arbuscules.

$N$. krauselii not only demonstrates the occurrence of different types of mycorrhizal associations, perhaps within a single fossil plant, but also provides some indirect evidence of the morphology, spatial distribution, and functioning of the root system in this Triassic voltzialean conifer with the surrounding environment. The specimens of $N$. krauselii were collected from the Fremouw Peak locality, which has been described as a warm, temperate high-latitude peat forming environment (Bomfleur et al., 2014). Modern peat forming ecosystems are highly acidic, nutrient poor environments. Plants utilize multiple strategies to adapt to these nutrient deficient, typically anoxic, low $\mathrm{pH}$ environments such as increasing root surface area via mycorrhizal fungi (Marschner, 1991; Clark et al., 1999). Moreover, mycorrhizas do occur in anoxic to low oxygen environments and are beneficial in maintaining species richness and uptake of phosphorous in wetland and peat ecosystems (Cornwell et al., 2001). Fungal activity is crucial in nutrient poor peatland environments (Myers et al., 2012), and it is therefore plausible that the AM fungus in the rootlets of $N$. krauselii were equally important for voltzialean conifers to survive within Triassic peat ecosystems.

Additionally, the discovery suggests that in this plant, mutualistic relationships perhaps occurred at multiple soil horizons. This might have been important with regard to survival of Notophytum krauselii in the

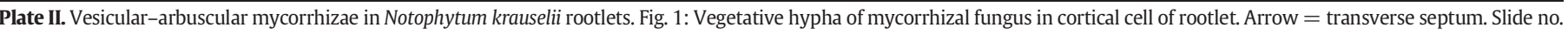

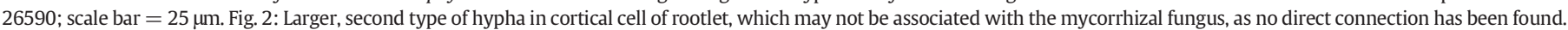

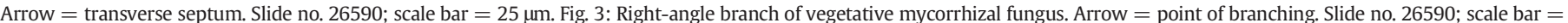

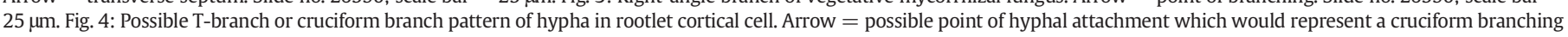

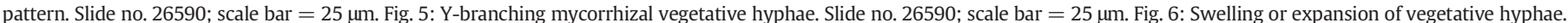

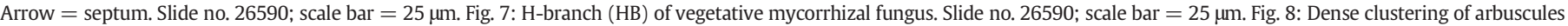

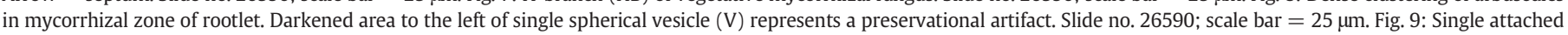

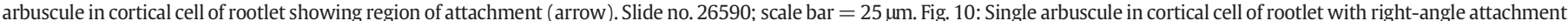

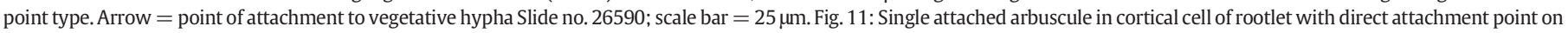

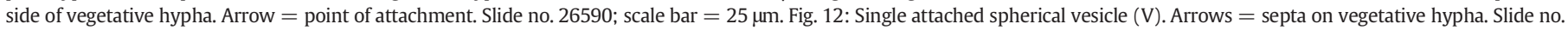

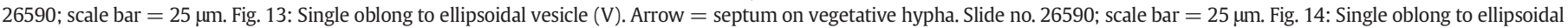

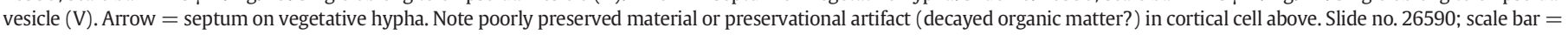
$25 \mu \mathrm{m}$.
} 
Antarctic high-latitude paleoecosystems. It has been suggested that the Middle Triassic climate of Antarctica was a warm temperate to temperate environment (Cúneo et al., 2003; Cantrill and Poole, 2012) with a high degree of seasonality as indicated by fossil tree-ring studies (Taylor and Ryberg, 2007; Gulbranson and Ryberg, 2013). Additionally, all of the necessary factors required for arborescent growth in highlatitude ecosystems (e.g., photoperiodic ecotypes, high rates of cambial activity during the growing season, appropriate crown architecture) are within the scope of adaptations to trees in polar forests (Creber, 1990; Osborne et al., 2004). One of the most significant abiotic stresses of these very high-latitude forests was the extreme light regime, i.e., four months of 24-hour darkness, four months of 24-hour daylight, and four months of transition (Taylor and Ryberg, 2007; Gulbranson et al., 2012). Additionally, extant studies and experiments on conifers show that arborescent organisms under extreme photoperiod regimes can retain the capacity to regenerate their photosynthetic pigments after time intervals of complete darkness, i.e., for up to 140 days (Larson, 1964; Kostopoulou et al., 2011). Furthermore, it is a well-understood phenomenon that under extremely stressful situations, extant trees increase carbon allocation to roots and mycorrhiza (McDowell et al., 2008; Evelin et al., 2009; Miransari, 2010; Swidrak et al., 2013). Perhaps the mycorrhizal fungi reported here were crucial to $N$. krauselii during periods of extreme light regimes. We cannot be sure if the plant was able to shift readily between different mycorrhizal associations during times of extreme biotic or abiotic stresses, the mycorrhizal types cooccurred with the same parent plant, or if each association occurred at different ontogenetic stages of $N$. krauselii during root development.

In extant gymnosperms, there can be multiple types of mycorrhizal interactions co-occurring within the same plant (Berliner and Torrey, 1989; Peterson et al., 2004). Most extant gymnosperms are characterized by having AM associations, e.g., cycads, Ginkgo, Araucariaceae, Podocarpaceae, Cupressaceae, Sciadopityaceae (Fontana, 1985; Halling, 2001; Fisher and Vovides, 2004; Peterson et al., 2004; Wagg et al., 2008; Brundrett, 2009). The fungal partners in these symbioses are typically of the Glomus type, or less commonly of the Gigaspora or Scutellospora types, and form vesicles and arbuscules (Baylis et al., 1963; Bonfante-Fasolo and Fontana, 1985; Russell et al., 2002; Wubet et al., 2003). On the other hand, mycorrhizal associations between gymnosperms and members of the Endogonales (Mucoromycotina, zygomycetous fungi) are generally considered ectomycorrhizal (Walker, 1985; Warcup, 1990) but gymnosperms can also have AM fungi that co-occur with ectomycorrhizal associations (Harley and Harley, 1987; Brundrett et al., 1990; Cázares and Trappe, 1993; Onguene and Kuyper, 2001; Wagg et al., 2008). Overall, the mycorrhizal ecology of gymnosperms is complex and occurrence of multiple types of mycorrhizal associations, and other endophytes, within the same plant in a common phenomenon in extant ecosystems (Vogt et al., 1983; Molina et al., 1992; Cázares et al., 2005; Menkis et al., 2005; Öpik et al., 2008). Therefore, it is surprising that there is a paucity of information about multiple mycorrhizas within fossil gymnosperms.

With the current report, there are now two fossil examples of different mycorrhizal associations occurring within the same plant from the Mesozoic. The other example is the Triassic cycad A. schopfii, also from the Middle Triassic of Antarctica, which contains two glomeromycotan fungi (Glomites and Gigasporites), each forming a morphologically distinctive endomycorrhizal association within the same roots (Stubblefield et al., 1987a,b; Phipps and Taylor, 1996). Gigasporites myriamyces is characterized by wide intercellular and intracellular hyphae that form intracellular loops and coils in the cells, whereas hyphae of Glomites cycestris are slightly narrower and produce thin-walled, elongate vesicles (Phipps and Taylor, 1996). Although there are two types of glomeromycotan fungi present within A. schopfii, this does not necessarily imply that each fungus was constantly in a mycorrhizal association. In extant plants that contain multiple mycorrhizal associations, these fungi may not necessarily form mycorrhizal symbioses at the same time (Helgason et al., 2002). The example in N. krauselii, however, demonstrates the presence of two endomycorrhizal associations; it remains to be demonstrated whether these interactions existed independently or functioned concurrently in the roots of this Triassic transitional conifer.

\section{Conclusions}

The presence of a vesicular arbuscular mycorrhiza in a Triassic voltzialean conifer, a member of a lineage considered intermediate between the Cordaitales and modern conifers, provides some interesting new insights into conifer evolution and paleobiology. We hypothesize that the progenitors of the conifers may have been predominately endomycorrhizal. Some support for this hypothesis comes from Carboniferous Radiculites-type cordaitalean rootlets showing evidence of AM colonization (Strullu-Derrien et al., 2009). However, more fossil evidence is needed to further resolve this hypothesis and the full extent of mycorrhizal evolution among conifers. We anticipate that future investigations of permineralized Triassic, Jurassic, and Cretaceous plants, spanning an important interval in the evolution of gymnospermmycorrhizal relationships, will provide opportunities to not only find earlier representatives of AM fossils, but perhaps also examples of the intermediate forms between endo- and ectomycorrhizal associations, and perhaps the earliest representatives of ectomycorrhizal interactions with ancient gymnosperms.

\section{Acknowledgments}

The authors greatly acknowledge the comments and suggestions provided by two anonymous reviewers, which greatly benefited this manuscript. Financial support was provided by the National Science Foundation (EAR-0949947 to T.N.T. and M.K.; OPP-0943934 to E.L.T. and T.N.T.), and the Alexander von Humboldt-Foundation (V-3.FLFDEU/1064359 to M.K.). We thank A.-L. Decombeix (Montpellier, France), B. Bomfleur (Stockholm, Sweden), R. Serbet (Lawrence, KS, USA), and A.B. Schwendemann (Greenwood, SC, USA) for the fruitful discussions, technical assistance, and constructive comments on the paper.

\section{References}

Abràmoff, M.D., Magelhães, P.J., Ram, S.J., 2004. Image processing with ImageJ. Biophoton. Int. 11, 36-42.

Anderson, H.M., 1978. Podozamites and associated cones and scales from the Upper Triassic Molteno Formation, Karoo Basin, South Africa. Palaeontol. Afr. 21, 57-77.

Anderson, J.M., Anderson, H.M., 2003. Heyday of the Gymnosperms: Systematics and Biodiversity of the Late Triassic Molteno Fructifications. National Botanical Institute, Pretoria, South Africa (398 pp.).

Axsmith, B.J., Taylor, T.N., Taylor, E.L., 1998. Anatomically preserved leaves of the conifer Notophytum krauselii (Podocarpaceae) from the Triassic of Antarctica. Am. J. Bot. 85, 704-713.

Baylis, G.T.S., McNabb, R.F.R., Morrison, T.M., 1963. The mycorrhizal nodules of podocarps Trans. Br. Mycol. Soc. 46, 378-384.

Beimforde, C., Schäfer, N., Dörfelt, H., Nascimbene, P.C., Singh, H., Heinrichs, J., Reitner, J. Rana, R.S., Schmidt, A.R., 2011. Ectomycorrhizas from a Lower Eocene angiosperm forest. New Phytol. 192, 988-996.

Bercovici, A., Hadley, A., Villanueva-Amadoz, U., 2009. Improving depth of field resolution for palynological photomicrography. Palaeontol. Electron. 12 (2) (12.2.5 T, 12 pp.).

Bergene, J.A., Taylor, E.L., Taylor, T.N., 2013. Dordrechtites arcanus sp. nov., an anatomically preserved gymnospermous reproductive structure from the Middle Triassic of Antarctica. Int. J. Plant Sci. 174, 250-265.

Berliner, R., Torrey, J.G., 1989. Studies on mycorrhizal associations in Harvard Forest Massachusetts. Can. J. Bot. 67, 2245-2251.

Biermann, B., Linderman, R.G., 1983. Use of vesicular-arbuscular mycorrhizal roots, intraradical vesicles and extraradical vesicles as inoculum. New Phytol. 95, 97-105.

Bomfleur, B., Serbet, R., Taylor, E.L., Taylor, T.N., 2011. The possible pollen cone of the Late Triassic conifer Heidiphyllum/Telemachus (Voltziales) from Antarctica. Antarct. Sci. 23 (4), 379-385.

Bomfleur, B., Decombeix, A.L., Escapa, I.H., Schwendemann, A.B., Axsmith, B., 2013. Whole-plant concept and environment reconstruction of a Telemachus conifer (Voltziales) from the Triassic of Antarctica. Int. J. Plant Sci. 174, 425-444

Bomfleur, B., Decombeix, A.L., Schwendemann, A.B., Escapa, I.H., Taylor, E.L., Taylor, T.N., McLoughlin, S., 2014. Habit and ecology of the Petriellales, an unusual group of seed plants from the Triassic of Gondwana. Int. J. Plant Sci. 175, 1062-1075. 
Bonfante, P., Selosse, M.A., 2010. A glimpse into the past of land plants and of their mycorrhizal affairs: from fossils to evo-devo. New Phytol. 186, 267-270.

Bonfante-Fasolo, P., 1984. Anatomy and morphology of VA mycorrhizae. In: Conway, L. Powell, D., Bagyaraj, D.J. (Eds.), VA Mycorrhiza. CRC Press, Boca Raton, FL, pp. 5-33.

Bonfante-Fasolo, P., Fontana, A., 1985. VAM fungi in Gingko biloba roots: their interactions at cellular level. Symbiosis 1, 53-67.

Breuninger, M., Einig, W., Magel, E., Cardoso, E., Hampp, R., 2000. Mycorrhiza of Brazil Pine (Araucaria angustifolia [Bert. O. Ktze.]). Plant Biol. 2, 4-10.

Brundrett, M., 2004. Diversity and classification of mycorrhizal associations. Biol. Rev. 79, 473-495.

Brundrett, M.C., 2009. Mycorrhizal associations and other means of nutrition of vascular plants: understanding the global diversity of host plants by resolving conflicting information and developing reliable means of diagnosis. Plant Soil 320, 37-77.

Brundrett, M.C., Murase, G., Kendrick, B., 1990. Comparative anatomy of roots and mycorrhizae of common Ontario trees. Can. J. Bot. 68, 551-578.

Cantrill, D.J., Poole, I., 2012. The Vegetation of Antarctica through Geological Time. Cambridge University Press, New York, NY (487 pp.).

Cázares, E., Trappe, J.M., 1993. Vesicular endophytes in roots of the Pinaceae. Mycorrhiza $2,153-156$.

Cázares, E., Trappe, J.M., Jumpponen, A., 2005. Mycorrhiza-plant colonization patterns on a subalpine glacier forefront as a model system of primary succession. Mycorrhiza 15, 405-406.

Clark, R.B., Zeto, S.K., Zobel, R.W., 1999. Arbuscular mycorrhizal fungal isolate effectiveness on growth and root colonization of Panicum viratum in acidic soil. Soil Biol. Biochem. 31, 1757-1763.

Cooper, K.M., Lösel, D.M., 1978. Lipid physiology of vesicular-arbuscular mycorrhiza. I. Composition of lipids in roots on onion, clover and ryegrass infected with Glomus mosseae. New Phytol. 80, 143-151.

Cornwell, W.K., Bedford, B.L., Chapin, C.T., 2001. Occurrence of arbuscular mycorrhiza fungi in a phosphorus-poor wetland and mycorrhizal response to phosphorus fertilization. Am. J. Bot. 88, 1824-1829.

Creber, G.T., 1990. The south polar forest ecosystem. In: Taylor, T.N., Taylor, E.L. (Eds.) Antarctic Paleobiology: Its Role in the Reconstruction of Gondwana. Springer-Verlag New York, NY, pp. 37-41.

Cúneo, N.R., Taylor, E.L., Taylor, T.N., Krings, M., 2003. In situ fossil forest from the upper Fremouw Formation (Triassic) of Antarctica: paleoenvironmental setting and paleoclimate analysis. Palaeogeogr. Palaeoclimatol. Palaeoecol. 197, 239-261.

Decombeix, A.-L., Bomfleur, B., Taylor, E.L., Taylor, T.N., 2014. New insights into the anatomy, development, and affinities of corystosperm trees from the Triassic of Antarctica. Rev. Palaeobot. Palynol. 203, 22-34.

Dickie, I.A., Holdaway, R.J., 2011. Podocarp roots, mycorrhizas, and nodules. In: Turner, B.L., Cernusak, L.A. (Eds.), Ecology of the Podocarpaceae in Tropical Forests. Smithsonian Contributions to Botany 95, pp. 175-187.

Dickson, S., 2004. The Arum-Paris continuum of mycorrhizal symbioses. New Phytol. 163, 187-200.

Escapa, I.H., Decombeix, A.L., Taylor, T.N., Taylor, E.L., 2010. Evolution and relationships of the conifer Telemachus: evidence from the Triassic of Antarctica. Int. J. Plant Sci. 171, 560-573.

Escapa, I.H., Taylor, E.L., Cúneo, R., Bomfleur, B., Bergene, J., Serbet, R., Taylor, T.N., 2011 Triassic floras of Antarctica: plant diversity and distribution in high paleolatitude communities. PALAIOS 26, 522-544.

Evelin, H., Kapoor, R., Giri, B., 2009. Arbuscular mycorrhizal fungi in alleviation of salt stress: a review. Ann. Bot. 104, 1263-1280.

Farabee, M.J., Taylor, E.L., Taylor, T.N., 1990. Correlation of Permian and Triassic palynomorphs from the central Transantarctic Mountains Antarctica. Rev. Palaeobot. Palynol. 65, 257-265.

Faure, G., Mensing, T.M., 2010. The Transantarctic Mountains: Rocks, Ice, Meteorites and Water. Springer, New York, NY (804 pp.).

Fisher, J.B., Vovides, A.P., 2004. Mycorrhizae are present in cycad roots. Bot. Rev. 70, 16-23.

Fitter, A.H., Gilligan, C.A., Hollingworth, K., Kleczkowski, A., Twyman, R.M., Pitchford, J.W. 2005. Biodiversity and ecosystem function in soil. Funct. Ecol. 19, 369-377.

Florin, R., 1951. Evolution in cordaites and conifers. Acta Horti Bergiani 15, 285-388.

Fontana, A., 1985. Vesicular-arbuscular mycorrhizas of Ginkgo biloba L. in natural and controlled conditions. New Phytol. 99, 441-447.

Galtier, J., Phillips, T.L., 1999. The acetate peel technique. In: Jones, T.P., Rowe, N.P. (Eds.) Fossil Plants and Spores: Modern Techniques. The Geological Society, London, pp. 67-70.

Gulbranson, E.L., Ryberg, P.E., 2013. Paleobotanical and geochemical approaches to studying fossil tree rings: quantitative interpretations of paleoenvironment and ecophysiology. PALAIOS 28, 137-140.

Gulbranson, E.L., Isbell, J.L., Taylor, E.L., Ryberg, P.E., Taylor, T.N., Flaig, P.P., 2012. Permian polar forests: deciduousness and environmental variation. Geobiology 10, 479-495.

Halling, R.E., 2001. Ectomycorrhizae: co-evolution, significance, and biogeography. Ann. Mo. Bot. Gard. 88, 5-13.

Hammer, W.R., 1990. Triassic terrestrial vertebrate faunas of Antarctica. In: Taylor, T.N., Taylor, E.L. (Eds.), Antarctic Paleobiology: Its Role in the Reconstruction of Gondwana. Springer-Verlag, New York, NY, pp. 42-50.

Harley, J.L., Harley, E.L., 1987. A check-list of mycorrhiza in the British flora. New Phytol. 105 (Suppl. s1), 1-102.

Harper, C.J., Taylor, T.N., Krings, M., Taylor, E.L., 2013. Mycorrhizal symbiosis in the Paleozoic seed fern Glossopteris from Antarctica. Rev. Palaeobot. Palynol. 192, 22-31.

Hass, H., Rowe, N.P., 1999. Thin sections and wafering. In: Jones, T.P., Rowe, N.P. (Eds.), Fossil Plants and Spores: Modern Techniques. The Geological Society, London, pp. 76-81.

Helgason, T., Merryweather, J.W., Denison, J., Wilson, P., Young, J., Fitter, A.H., 2002. Selectivity and functional diversity in arbuscular mycorrhizas of co-occurring fungi and plants from a temperate deciduous woodland. J. Ecol. 90, 371-384.
Hernandez-Castillo, G.R., Rothwell, G.W., Mapes, G., 2001. Compound pollen cone in a Paleozoic conifer. Am. J. Bot. 88, 1139-1142.

Joy, K.W., Willis, A.J., Lacey, W.S., 1956. A rapid cellulose peel technique in palaeobotany. Ann. Bot. 20, 635-637.

Kostopoulou, P., Radoglou, K., Dini-Papanastasi, O., 2011. Performance and quality of Cupressus sempervirens L. mini-plug seedlings under reduced photoperiod. Eur. J. For. Res. 130, 579-588.

Krings, M., Taylor, T.N., Hass, H., Kerp, H., Dotzler, N., Hermsen, E.J., 2007. Fungal endophytes in a 400-million-yr-old land plant: infection pathways, spatial distribution, and host responses. New Phytol. 174, 648-657.

Krings, M., Taylor, T.N., Taylor, E.L., Dotzler, N., Walker, C., 2011. Arbuscular mycorrhizallike fungi in Carboniferous arborescent lycopsids. New Phytol. 191, 311-314.

Krings, M., Taylor, T.N., Dotzler, N., Persichini, G., 2012. Fossil fungi with suggested affinities to the Endogonaceae from the Middle Triassic of Antarctica. Mycologia 104, 835-844.

Larson, P.R., 1964. Contribution of different-aged needles to growth and wood formation of young red pines. For. Sci. 10, 224-238

LePage, B.A., Currah, R.S., Stockey, R.A., Rothwell, G.W., 1997. Fossil ectomycorrhizae from the Middle Eocene. Am. J. Bot. 84, 410-412.

Marschner, H., 1991. Mechanisms of adaptation of plants to acid soils. In: Wright, R.J., et al. (Eds.), Plant-Soil Interactions at low pH: Proc. Second Intl. Symp. on Plant-soil Interactions at low pH, Beckley, WV, 24-29 June 1991. Kluwer Academic Publisher, Dordrecht, the Netherlands, pp. 683-702.

McDowell, N., Pockman, W.T., Allen, C.D., Breshears, D.D., Cobb, N., Kolb, T., Plaut, J., Sperry, J., West, A., Williams, D.G., Yepez, E.A., 2008. Mechanisms of plant survival and mortality during drought: why do some plants survive while others succumb to drought? New Phytol. 178, 719-739.

McGee, P.A., Bullock, S., Summerell, B.A., 1999. Structure of mycorrhizae of the Wollemi Pine (Wollemia nobilis) and related Araucariaceae. Aust. J. Bot. 47, 85-95.

Menkis, A., Vasiliauskas, R., Taylor, A.F.S., Stenlid, J., Finlay, R., 2005. Fungal communities in mycorrhizal roots of conifer seedlings in forest nurseries under different cultivation systems, assessed by morphotyping, direct sequencing and mycelial isolation. Mycorrhiza 16, 13-41.

Meyer-Berthaud, B., Taylor, T.N., 1991. A probable conifer with podocarpacean affinities from the Triassic of Antarctica. Rev. Palaeobot. Palynol. 67, 179-198.

Meyer-Berthaud, B., Taylor, T.N., 1992. Permineralized conifer axes from the Triassic of Antarctica. Cour. Forschungsinst. Senckenberg 147, 191-197.

Millay, M.A., Taylor, T.N., Taylor, E.L., 1987. Phi thickenings in fossil seed plants from Antarctica. IAWA Bull. 8, 191-201.

Miransari, M., 2010. Contribution of arbuscular mycorrhizal symbiosis to plant growth under different types of soil stress. Plant Biol. 12, 563-569.

Molina, R., Massicotte, H., Trappe, J.M., 1992. Specificity phenomena in mycorrhizal symbioses: community-ecological consequences and practical implications. In: Allen, M. (Ed.), Mycorrhizal Functioning: An Integrative Plant-Fungal Process. Routledge, Chapman, \& Hall Inc., New York, NY, pp. 357-423.

Morton, J.B., Benny, G.L., 1990. Revised classification of arbuscular mycorrhizal fungi (Zygomycetes): a new order, Glomales, two new suborders, Glomineae and Gigasporineae, and two new families, Acaulosporaceae and Gigsporaceae, with an emendation of Glomaceae. Mycotaxon 37, 471-491.

Morton, J.B., Redecker, D., 2001. Two new families of Glomales, Archaeosporaceae and Paraglomaceae, with two new genera Archaeospora and Paraglomus, based on concordant molecular and morphological characters. Mycologia 93, 181-195.

Myers, B., Webster, K.L., Mclaughlin, J.W., Basiliko, N., 2012. Microbial activity across boreal peatland nutrient gradient: the role of fungi and bacteria. Wetlands Ecol. Manage. 20, 77-88

Oehl, F., Sieverding, E., 2004. Pacispora, a new vesicular arbuscular mycorrhizal fungal genus in the Glomeromycetes. J. Appl. Bot. 78, 72-82.

Onguene, N.A., Kuyper, T.W., 2001. Mycorrhizal associations in the rain forest of South Cameroon. For. Ecol. Manag. 140, 277-287.

Öpik, M., Moora, M., Zobel, M., Saks, Ü., Wheatley, R., Wright, F., Daniell, T., 2008. High diversity of arbuscular mycorrhizal fungi in a boreal herb-rich coniferous forest. New Phytol. 179, 867-876.

Osborn, J.M., Taylor, T.N., 1989. Palaeofibulus gen. nov., a clamp-bearing fungus from the Triassic of Antarctica. Mycologia 81, 622-626.

Osborne, C.P., Royer, D.L., Beerling, D.J., 2004. Adaptive role of leaf habit in extinct polar forests. Int. For. Rev. 6, 181-186

Peterson, R.L., Farquhar, M.L., 1994. Mycorrhizas: integrated development between roots and fungi. Mycologia 86, 311-326.

Peterson, R.L., Massicotte, H.B., Melville, L.H., 2004. Mycorrhizas: Anatomy and Cell Biology. NRC Research Press, CABI Publishing, Ottawa, Canada (173 pp.).

Phipps, C.J., Taylor, T.N., 1996. Mixed arbuscular mycorrhizae from the Triassic of Antarctica. Mycologia 88, 707-714.

Pirozynski, K.A., Dalpé, Y., 1989. Geological history of the Glomaceae with particular reference to mycorrhizal symbiosis. Symbiosis 7, 1-36.

Pirozynski, K.A., Malloch, D.W., 1975. The origin of land plants: a matter of mycotrophism. BioSystems 6, 153-164

Redecker, D., Schüßler, A., Stockinger, H., Stürmer, S.L., Morton, J.B., Walker, C., 2013. An evidence-based consensus for the classification of arbuscular mycorrhizal fungi (Glomeromycota). Mycorrhiza 23, 515-531. http://dx.doi.org/10.1007/s00572-0130486-y.

Remy, W., Taylor, T.N., Hass, H., Kerp, H., 1994. Four hundred-million-year-old vesicular arbuscular mycorrhizae. Proc. Natl. Acad. Sci. U. S. A. 91, 11841-11843.

Rillig, M.C., Mummey, D.L., 2006. Mycorrhizas and soil structure. New Phytol. 171, 41-53.

Rothwell, G.W., Mapes, G., Hernandez-Castillo, G.R., 2005. Hanskerpia gen. nov. and phylogenetic relationships among the most ancient conifers (Voltziales). Taxon 54, 733-750. 
Russell, A.J., Bidartondo, M.I., Butterfield, B.G., 2002. The root nodules of the Podocarpaceae harbour arbuscular mycorrhizal fungi. New Phytol. 156, 283-295.

Saupe, E.E., Selden, P.A., 2009. First fossil Mecysmaucheniidae (Arachnida, Chelicerata, Araneae), from Lower Cretaceous (uppermost Albian) amber of Charente-Maritime, France. Geodiversitas 31, 49-60.

Schüßler, A., 2002. Molecular phylogeny, taxonomy, and evolution of Geosiphon pyriformis and arbuscular mycorrhizal fungi. Plant Soil 244, 75-83.

Schüßler, A., Walker, C. (Eds.), 2010. The Glomeromycota. A Species List with new Families and new Genera. The Royal Botanic Garden Edinburgh, The Royal Botanic Garden Kew, Botanische Staatssammlung Munich, and Oregon State University (Electronic edition updated 2011, retrieved from www.amf-phylogeny.com; species list updated 2013, retrieved from http://schuessler.userweb.mwn.de/amphylo/).

Schwendemann, A.B., Decombeix, A.L., Taylor, T.N., Taylor, E.L., Krings, M., 2011. Morphological and functional stasis in mycorrhizal root nodules as exhibited by a Triassic conifer. Proc. Natl. Acad. Sci. U. S. A. 108, 13630-13634.

Sidor, C.A., Damiani, R., Hammer, W.R., 2008. A new Triassic temnospondyl from Antarctica and a review of Fremouw Formation biostratigraphy. J. Vertebr. Paleontol. 28, 656-663.

Simard, S.W., Durall, D.M., 2004. Mycorrhizal networks: a review of their extent, function, and importance. Can. J. Bot. 82, 1140-1165.

Simon, L., Bousquet, J., Lévesque, R.C., Lalonde, M., 1993. Origin and diversificiation of endomycorrhizal fungi and coincidence with vascular land plants. Nature 363, 67-69.

Stockey, R.A., Rothwell, G.W., Addy, H.D., Currah, R.S., 2001. Mycorrhizal association of the extinct conifer Metasequoia milleri. Mycol. Res. 105, 202-205.

Strullu-Derrien, C., Rioult, J.P., Strullu, D.G., 2009. Mycorrhizas in Upper Carboniferous Radiculites-type cordaitalean rootlets. New Phytol. 182, 561-564.

Strullu-Derrien, C., Kenrick, P., Pressel, S., Duckett, J.G., Rioult, J.-P., Strullu, D.-G., 2014. Fungal associations in Horneophyton ligneri from the Rhynie Chert (c. 407 million year old) closely resemble those in extant lower land plants: novel insights into ancestral plant-fungus symbioses. New Phytol. 203, 964-979.

Stubblefield, S.P., Taylor, T.N., Trappe, J.M., 1987a. Fossil mycorrhizae: a case for symbiosis. Science 237, 59-60.

Stubblefield, S.P., Taylor, T.N., Trappe, J.M., 1987b. Vesicular-arbuscular mycorrhizae from the Triassic of Antarctica. Am. J. Bot. 74, 1904-1911.

Swidrak, I., Schuster, R., Oberhuber, W., 2013. Comparing growth phenology of cooccurring deciduous and evergreen conifers exposed to drought. Flora 208, 609-617.

Taylor, E.L., Ryberg, P.E., 2007. Tree growth at polar latitudes based on fossil tree ring analysis. Palaeogeogr. Palaeoclimatol. Palaeoecol. 225, 246-264.

Taylor, T.N., Taylor, E.L., Collinson, J.W., 1986. Paleoenvironment of Lower Triassic plants from the Fremouw Formation. Antarct. J. U.S. 21, 26-27.
Taylor, E.L., Taylor, T.N., Collinson, J.W., 1989. Depositional setting and paleobotany of Permian and Triassic permineralized peat from the central Transantarctic Mountains. Int. J. Coal Geol. 12, 657-679.

Taylor, T.N., Taylor, E.L., Krings, M., 2009. Paleobotany: The Biology and Evolution of Fossil Plants. Second edition. Academic Press, Burlington, MA (1230 pp.).

Vogt, K.A., Edmonds, R.L., Grier, C.C., 1981. Seasonal changes in biomass and vertical distribution of mycorrhizal and fibrous-textured conifer fine roots in 23- and 180year-old subalpine Abies amabilis stands. Can. J. For. Res. 11, 224-230.

Vogt, K.A., Moore, E.E., Vogt, D.J., Redlin, M.J., Edmonds, R.L., 1983. Conifer fine root and mycorrhizal root biomass within the forest floors of Douglas-fir stands of different ages and site productivities. Can. J. For. Res. 13, 429-437.

Wagg, C., Pautler, M., Massicotte, H.B., Peterson, R.L., 2008. The co-occurrence of ectomycorrhizal, arbuscular mycorrhizal, and dark septate fungi in seedlings of four members of the Pinaceae. Mycorrhiza 18, 103-110.

Walker, C.A., 1985. Endogone lactiflua forming ectomycorrhizas with Pinus contorta. Trans. Br. Mycol. Soc. 84, 353-355.

Walker, C.A., Sanders, F.E., 1986. Taxonomic concepts in the Endogonaceae: III. The separation of Scutellospora gen. nov. from Gigaspora Gerd. \& Trappe. Mycotaxon 27 169-182.

Walker, C., Schüßler, A., 2004. Nomenclatural clarifications and new taxa in the Glomeromycota. Mycol. Res. 108, 979-982.

Wang, B., Qiu, Y.L., 2006. Phylogenetic distribution and evolution of mycorrhizas in land plants. Mycorrhiza 16, 299-363.

Warcup, J.H., 1990. Taxonomy, culture and mycorrhizal associations of some zygosporic Endogonaceae. Mycol. Res. 94, 173-176.

White, J.F., Taylor, T.N., 1989a. A trichomycete-like fossil from the Triassic of Antarctica. Mycologia 81, 643-646.

White, J.F., Taylor, T.N., 1989b. Triassic fungi with suggested affinities to the Endogonales (Zygomycotina). Rev. Palaeobot. Palynol. 61, 53-61.

White, J.F., Taylor, T.N., 1989c. An evaluation of sporocarp structure in the Triassic fungus Endochaetophora. Rev. Palaeobot. Palynol. 61, 341-345.

Wubet, T., Weiß, M., Kottke, I., Oberwinkler, F., 2003. Morphology and molecular diversity of arbuscular mycorrhizal fungi in wild and cultivated yew (Taxus baccata). Can. J. Bot. 81, 255-266.

Yao, X., Taylor, T.N., Taylor, E.L., 1993. The Triassic seed cone Telemachus from Antarctica. Rev. Palaeobot. Palynol. 78, 269-276. 